\title{
The trial of Maurice Papon for crimes against humanity and the concept of bureaucratic crime
}

\author{
Robert Boyce
}

The trial of Maurice Papon in the assize court of Bordeaux over the winter of 1997-98 was noteworthy for several reasons. In the first place, the crimes for which he was charged had been committed more than half a century before the trial began. None of the three judges and only one of the nine jurors had even been born at the time the crimes occurred. ${ }^{1}$ To assist the jurors to understand the circumstances surrounding the case, therefore, the state prosecutor as well as Papon's defence team were permitted to call upon a number of leading historians to describe the circumstances surrounding the events in question. This was a historic trial in more ways than one.

A second feature of the trial arose out of the nature of the charges. Papon, an official of the wartime Vichy regime, was charged with crimes against humanity for ordering the arrest and detention of nearly 1,600 Jews in Bordeaux where he was posted and their transfer to the transit camp at Drancy, north of Paris, from where they were deported to Auschwitz. He was thus charged not with one crime but with hundreds of crimes committed between June 1942 and May 1944. The acte d'accusation, a document of over a hundred pages, required two days of court time to read out, and between 8 October 1997 when the trial began and 2 April 1998 when the verdict was announced, 133 witnesses, dozens of depositions, and fifty thousand pages of documents were produced in court. This made it the longest and probably also the most expensive trial in French history. ${ }^{2}$ It was also one of the most widely publicised. Every national newspaper and television channel provided regular coverage, and by the close Papon, Jean-Marc Varaut, Papon's chief counsel, Arno Klarsfeld, counsel for the children of the victims, and Jean-Louis Castagnède, the presiding judge, had become familiar names in France. ${ }^{3}$

A third feature of the trial was the status of the accused. This was not the first time a Vichy official had faced trial in France. Contrary to a still-popular myth that France has never faced up to its wartime record but preferred to sweep its crimes under the carpet, in the seven years after the Liberation 
over 124,000 Frenchman were brought to trial and more than 75 per cent of them were convicted of war crimes, mostly for collaboration with the occupying power or attacks against the Resistance. Marshal Philippe Pétain, head of the Vichy regime, was convicted of collaboration, although his death sentence was commuted to life imprisonment. Pierre Laval, twice Prime Minister under Pétain, was convicted and shot. Members of the prefectoral corps to which Papon belonged were purged with particular thoroughness. Of the approximately one hundred who had served Vichy, sixty were dismissed, two were shot, and a third was sentenced to death before having his sentence commuted to life; only six were kept in post, while the rest were transferred to other jobs. ${ }^{4}$ Nor was that the end of it. In response to growing interest in France's role in the Holocaust, dossiers were re-opened and starting in 1975 several leading Vichy officials were charged with crimes against humanity. ${ }^{5}$ Two were convicted, another died after charges were laid, and a fourth was assassinated by a deranged attacker prior to trial. ${ }^{6}$ But in each of these cases the accused had been directly involved in wartime crimes as policeman, gaoler, or torturer, or as author of the policy that gave rise to the offence. ${ }^{7}$ The same could not be said of Papon. At the time of the crimes for which he was charged, he was Secretary-General of the Prefecture in Bordeaux: a middle-ranking official who received orders from persons higher up the administrative chain and transmitted them to persons further below. His only weapon was his pen, and in most instances he never even saw his victims, who remained merely entries on his lists. For this reason, Papon could not be dismissed at his trial as the unacceptable face of Vichy. To all intents and purposes he was a representative figure of Vichy's administrative machine, a faithful executor of its policy. Despite Judge Castagnède's repeated protests that the trial was of one man, not of a whole political system, Papon was almost universally regarded as a proxy for the Vichy regime, and in the liberal media at least, his conviction was treated as the condemnation of Vichy as a whole.

A fourth feature of the trial was the remarkable range of hopes and fears attendant upon its outcome. To the surviving victims and their children, this was the opportunity long denied them of securing justice and obtaining some release from the frustration of watching terrible crimes go unpunished. To others not directly involved, it promised a salutary lesson for those tempted to support the extreme right-wing National Front, which shares a common heritage with Vichy and which had recently scored impressive election victories in several parts of France. Not all observers, however, were hopeful that good would come from the trial. Not a few, including several who were sympathetic to the victims, feared the result of relying upon the courts to improve public understanding of the past, when the actions of one age would inevitably be judged by the standards of another. This almost certainly was the reason why François Mitterrand was cool towards the prosecution of Papon and may have used his influence as president in the 1980s to delay the proceedings. 'Quand on n'a pas eu 20 ans en 1940, on n'a rien à dire sur Vichy', 
he had once observed. As a former employee of Vichy who had known Papon since 1954 and been a close acquaintance of the Vichy chief of police, René Bousquet, it could be said that Mitterrand had a personal interest in letting sleeping dogs lie. ${ }^{9}$ But Simone Veil, a Cabinet minister under Valerie Giscard d'Estaing, Mitterrand's predecessor, and an Auschwitz survivor, could in no way be described as a Vichy sympathiser. Yet she dissociated herself from the trial for similar reasons. ${ }^{10}$ Another was Henri Rousso, Director of the Institut d'Histoire du Temps Présent and author of the highly regarded study of Vichy and modern memory Le Syndrôme de Vichy. He had been requested to appear as an expert witness by Papon's defence counsel, who evidently hoped to exploit Rousso's argument about the relativity of perceptions of the past to underline the dangers of convicting a man so many years after the crimes were committed. Rousso refused to be made use of for such partisan purposes. ${ }^{11}$

There were also those who feared that by raking over the coals of the Second World War the trial would damage Franco-German relations and in turn compromise French influence within the European Union. ${ }^{12}$ And there were those who worried that the trial might undermine the reputation of contemporary conservatism in France itself because of Papon's post-war associations. At the Liberation in 1944, General Charles de Gaulle kept Papon in post, and upon returning to public office in 1958 he appointed Papon the Prefect of Police in Paris, a post he occupied in October 1961 when the police crushed a peaceful, if illegal, demonstration in favour of Algerian independence with extraordinary brutality and extensive loss of life. ${ }^{13}$ When Papon retired from the prefectoral service in 1967, he received the plum job of President of Sud Aviation, a public sector company. The following year he was elected to Parliament as a member of the Gaullist Party, the Union Democratique Républicaine (UDR), replaced by the Rassemblement pour la République (RPR) after 1976. He ended his public career as Minister for the Budget in 1978-81 under Giscard d'Estaing, head of the liberal Union Democratique Française (UDF). Thus both wings of French conservatism were indirectly implicated by Papon, and for the sake of France's domestic harmony as well as its German and European relations, some observers would have preferred that the trial be indefinitely postponed. ${ }^{14}$

Despite the risks and inconvenience, however, the trial offered the possibility of squaring up to the past and exposing the real character of the Vichy state to a new generation that might not otherwise understand what it had done in France's name. In particular, it would provide insights into the motivations of the Vichy civil service: a means of explaining why a man like Papon should have participated in the systematic mistreatment of refugees and French citizens. Complete agreement on these issues was probably out of the question, but at the trial's conclusion most observers, witnesses, and even, it seems, jurors appear to have accepted that important new light had been shed upon this dark chapter in French history. Papon was widely portrayed as an arch-example of a bureaucratic criminal: one who from the remoteness 
of an administrative office had contributed to immoral or inhuman policies out of indifference or personal advancement. ${ }^{15}$ This was a very different explanation from the older ones based upon assumptions that the French authorities had been forced into anti-semitic policies by the German occupiers or that the French had been inspired by their own anti-semitic prejudices. There are, however, grounds for doubting whether the images of Vichy or of Papon presented by the trial constitute an important advance in our understanding of the past.

\section{The peculiar origins of a bureaucratic criminal}

The puzzle surrounding Papon's motives is illustrated by examining briefly his early life in order to see what values prevailed up to the time of Vichy. He was born in September 1910 into a middle-class and strongly republican family in Gretz-Armainvilliers, a town 25 kilometres east of Paris. His father, a notary by profession and founder of a thriving glass-manufacturing firm, was an active member of the local Radical Socialist Party. The largest party in the country, the Radicals presented themselves as the chief defenders of republican principles. Prominent in his father's circle were the two Radical Deputies for the Seine-et-Marne department, Jacques-Louis Dumesnil and François de Tessan, who were later to help the young Papon in his administrative career. Both men had long and highly successful political careers, culminating in a succession of ministerial posts in interwar governments, but in 1940 Dumesnil voted emergency powers for Marshal Pétain, for which he was banned from holding public office after the Liberation. De Tessan also voted for emergency powers, but soon joined the Resistance and died in the Nazi concentration camp at Dachau. ${ }^{16}$ Their contrasting fates are illustrative of the dilemmas that confronted the liberal Third Republic and Papon himself after the outbreak of war.

A promising student, Papon graduated from the local primary school at Gretz-Armainvilliers and at the age of 11 went up to Paris to study for his baccalaureat at the Lycée Montaigne, and from there to the Lycée Louis-le-Grand, one of the great preparatory schools of Paris, to prepare for university. In 1929 he entered the faculty of law at the University of Paris. Upon gaining his licence, he spent two years at the military academy of Saint-Cyr, where he obtained a commission as a sub-lieutenant in the colonial infantry, before returning to complete his studies. At this point he took up political economy and public law, and entered the Ecole des sciences politiques to study public finance. Having obtained diplomas in law (mention bien) and political economy (mention très bien), and narrowly failing the concours for the Inspection générale des finances, he sat the civil service examinations in July 1935 and gained a post in the Ministry of the Interior. For eighteen months, from June 1936 to January 1938, he was seconded to assist de Tessan, first at the Présidence du Conseil and then the Foreign Ministry when de Tessan served as a secretary of 
state in the Popular Front governments. Thereafter he returned to the Ministry of the Interior until August 1939, when his request to rejoin the army was approved.

This was, by and large, a conventional trajectory for an entrant to the upper civil service of Papon's day, yet there are at least two features of his path that deserve mention. The first is his cultural and intellectual maturity. Papon demonstrated this during his student days in several ways, including his close interest in the theatre and his pursuit of diploma courses in psychology and sociology in addition to political economy at the Ecole libre des sciences politiques and his legal studies at the Sorbonne. The second is his intense patriotism, expressed through active commitment to liberal and republican causes. One example was his decision to join the Ligue d'Action Universitaire Républicaine et Socialiste (LAURS). Throughout his time as a student both the law faculty at the Sorbonne and the Sciences Pô were strongholds of right wing, anti-parliamentary ligues, notably the Camelots $d u$ Roi, the youth movement of Action Française. Indeed, only three years before Papon's arrival, the law faculty had erupted in rioting after a professor associated with the RadicalSocialist Party was nominated to an empty chair. ${ }^{17}$ LAURS specialised in countering ligue demonstrations and their nationalist, anti-semitic policies, and later leading LAURS members were to become prominent in the wartime Resistance and post-Liberation politics. During Papon's student days its secretary was Pierre Mendès France, a Jew and future premier of France. Membership in LAURS was a notable act of independence on Papon's part, and a reflection of the seriousness with which he confronted public affairs. Nor did his commitment to republicanism and human rights end with his formal studies and entry into the civil service. Significantly, de Tessan, his political mentor, published a book entitled Voici Adolf Hitler, an early warning against the menace from the east. Between 1937 and 1939 Papon himself wrote occasionally for Le Jacobin, a small radical publication financed by a Jewish businessman, which distinguished itself by its stand against the policy of appeasement. ${ }^{18}$ In 1938, by now married with a young family and living in somewhat cramped quarters, he provided shelter for some months to a Jewish friend from student days, who had been forced to flee Vienna after the Anschluss. ${ }^{19}$ These episodes in Papon's early life were described at his trial and went unchallenged. By common consent there had been nothing in Papon's life before the war that pointed towards bigotry, race hatred, sympathy for fascism, or narrow, self-serving ambition; rather the contrary. ${ }^{20}$

On 10 May 1940 German armies invaded the Low Countries and France. The attack had long been anticipated but not the location of its Schwerpunkt nor its massive armoured follow-through. French forces that had advanced into Belgium were cut off and obliged to surrender. The rest of the army was thrown back in disarray, the British expeditionary force was hastily withdrawn to Dunkirk, and within six weeks the Battle of France had turned into a rout. The President of the Council, Paul Reynaud, resigned on 16 June, handing over 
to Pétain, the First World War hero and recently appointed Vice-President, who immediately requested an armistice. Humiliated, deputies and senators of the two Houses of the French Parliament retreated to Bordeaux, then to Vichy when Bordeaux was placed under direct German control. They met on 10 July in Vichy's municipal casino - the only building large enough to hold them - and voted overwhelmingly to accord Pétain exceptional powers. Within days, he began to implement his so-called National Revolution. This was, in fact, a counter-revolution: the revenge of the anti-dreyfusards, the adherents of the interwar ligues, the devotees of Charles Maurras, and all the enemies of the Popular Front, who sought to sweep away a century and a half of liberalism and to erect in its place a narrowly nationalist and authoritarian state. Called l'Etat Français, the very word republic was effaced and the motto liberté, égalité, fraternité was replaced by the triad travail, famille, patrie, borrowed directly from Maurras's Action Française, the most influential of the rightwing anti-parliamentary associations. The Vichy regime, as it has come to be known, gave expression to an exclusive view of French society, targeting freemasons, Protestants, the foreign-born, and Jews - particularly Jews - for exclusion. Days after emergency powers were voted, Vichy introduced the first orders restricting Jewish rights and freedoms. In August it lifted legal restrictions on anti-semitism in the media. And on 3 October it adopted the first of three statuts des juifs, which employed for the first and only time in French history the criterion of race as the basis of citizenship in order to exclude Jews from civil society. ${ }^{21}$

Papon was still at his army post on the Syrian frontier with Turkey when the first statut was introduced and may not have been fully aware of the racist foundations of the National Revolution. But he was soon demobilised, and before the end of October 1940 he was back at the Ministry of the Interior in Vichy, where he came under the wing of Maurice Sabatier, a senior colleague who had taken an interest in his career since 1936. With many officials either prisoners of war or dismissed as a result of the anti-semitic laws and the work of the Ministry increasing, Sabatier had rapidly ascended the administrative ladder. In 1940 he had become responsible for Algerian affairs, thus participating in the preparation and distribution of anti-semitic orders in North Africa. When the Ministry was reorganised into three main sections in October of that year, Sabatier became chief of the section responsible for departmental and local affairs. In February 1941 Admiral Jean-François Darlan, the head of government, appointed him to the newly created post of Secretary-General for Administration. Two months later the Germans replaced Darlan with Laval, who conducted a further shake-up of the Ministry, promoting officials prepared to support his policy of more active collaboration while relegating those who seemed less enthusiastic. The post of regional prefect - with executive authority for two or more departments - had recently been created, and Sabatier became Regional Prefect for the Aquitaine with authority for the Gironde, the Landes, and the Basses-Pyrénées departments, and centred on Bordeaux. 
Papon's career advanced in lockstep with Sabatier's, including no less than five promotions in eighteen months. The last was his nomination as SecretaryGeneral of the Prefecture of the Gironde in May 1942. In effect, he became Sabatier's deputy, and indeed on 20 June Sabatier delegated to him authority over a number of the most sensitive issues, including dealings with German occupation officials and the Jewish question. ${ }^{22}$ The documents presented at Papon's trial confirmed that he wasted no time fulfilling his expanded duties. Within four days, his signature appeared on orders for the mass arrest of enemy aliens and the enumeration of foreign Jews. On 18 July the first convoy of 171 detainees left Bordeaux for Drancy, and thence to 'the East'. Over the next two years ten more convoys followed, carrying altogether 1,560 individuals including infants, elderly, and seriously ill victims. Through the efforts of Papon and the local gendarmerie, Bordeaux yielded up relatively more Jews to the Holocaust than the French average. ${ }^{23}$

\section{Papon's defences analysed}

While not denying involvement in the deportations, Papon and his lawyers presented an elaborate rationale for his denial of responsibility for the tragic outcome. He claimed that he and French colleagues had had little choice but to act as they had done, because German authorities had closely monitored their actions and possessed their own sources of information on the local Jewish and refugee population. ${ }^{24}$ With the Germans looking over their shoulders, French administrators had been bound to give the impression of diligence in following up orders. ${ }^{25}$ This informed much of the documentation presented in the court. Since it had been produced with the German occupiers in mind, it could not be taken at face value and did not support the construction the prosecution placed upon it. In fact, French administrators had had an unwritten rule to go slow, and whenever possible Papon himself had sought to mitigate the harshness of the anti-Jewish policies, including the removal of over a hundred Jews from the deportation lists. ${ }^{26}$ Moreover, while still in Vichy he had entered into contact with the Resistance, on several occasions risking his life to render them assistance. ${ }^{27} \mathrm{He}$ also claimed that, as a matter of principle, French administrative tradition allowed the delegation of authority but not of responsibility. ${ }^{28}$ Hence it was Sabatier, his superior, who bore responsibility for the deportations that Papon had helped to organise. ${ }^{29}$ He further insisted that he had not exercised authority over the police who carried out the mass arrests or over the detention camp from which victims were deported. ${ }^{30}$ More emphatically, he claimed that he had not known, and could not have known, the fate of his victims: his task had been to detain them and have them transferred to Drancy. What had happened to them after they passed into German hands had only become known after the war. ${ }^{31}$

Certain elements of Papon's defence were by no means implausible. It is true that in France generally, as Robert Paxton, a Columbia University 
historian, explained to the court, the German occupiers were too few in number to carry out their repressive policies without the collaboration of French officials, who hence bear a heavy responsibility for the consequences. But Bordeaux itself was strongly held and the local French administration closely monitored on account of the city's strategic importance as an Atlantic port and naval base. Evidence also existed to show that Papon did render limited assistance to individual members of the Resistance in 1943 and 1944. His claim to have made contact with the Resistance as early as 1940 and to have actively worked for the Resistance almost from the moment he arrived at Bordeaux, however, was heavily suspect. ${ }^{32}$ As proof, Papon produced his attestation of Resistance membership along with four witnesses prepared to corroborate his claim. However, the court also heard that his request to be regarded as a Resister had been refused several times after the war, and only when he obtained the influential post of prefect of police in Paris in 1958, had his claim been registered. ${ }^{33}$ As for those called to testify on his behalf, all of them admitted that they had no direct knowledge of his Resistance exploits, while other Resistance leaders in a position to judge his claims had little or nothing to say in his favour. Papon thus appeared to have been 'un résistant du débarquement', as one of the counsel for the victims put it: an eleventh-hour Resister, who had sought to create an alibi for himself when the course of the war turned decisively in the Allies' favour. ${ }^{34}$ The German penetration and near-total destruction of the Resistance organisation in the Bordeaux region makes it more than usually difficult to be certain about the wartime events. But the evidence presented in the courtroom left little room for doubt that until the liberation of Bordeaux, Papon's first loyalty had been to the Vichy state, which had mounted a sustained campaign to crush the Resistance.

Other elements of his defence were comprehensively challenged. His claim that delegated authority carried with it no responsibility for the outcome, for instance, found support from only one other witness while being strongly disputed by others. ${ }^{35}$ The prosecuting counsel pointed out that Papon's theory, if carried to its logical extreme, would leave Pétain to bear sole responsibility for all acts committed in Vichy's name. ${ }^{36}$ Papon's own testimony revealed him to be far from consistent in applying the theory. Sometimes he insisted that his superior Sabatier had been to blame, while at other times he exonerated Sabatier on the grounds that he too had been under orders, and not infrequently Papon sought to deflect responsibility from himself onto his own subordinates, in particular the local police official in charge of arresting Jews. As for Papon's claim to have mitigated the worst consequences of the deportation policy, this was largely contradicted by the frequently chilling testimony of the surviving victims and other witnesses.

For example, it was shown that one of Papon's first acts on becoming Secretary-General of the Prefecture in Bordeaux had been to order ('très urgent') the arrest of four 'foreigners' and their transfer to Drancy. According to a police report in his possession, two of the four were foreigners and two 
French citizens, and of the four two were Catholic, one was 'without religion', and the fourth was Jewish. But in the report Papon subsequently prepared they appeared quite differently: instead of nationalities only their birthplaces were given, which made them all appear to be foreign, one of the Catholics and the individual 'without religion' became Jewish, and the second Catholic became 'without religion'. Why Papon, usually a stickler for detail, should have misrepresented them is unclear. But the practical consequence was to make them all liable to be seized by the Germans and deported to concentration camps. ${ }^{37}$ Another of Papon's early acts had been to instruct prefectoral officials to update and expand their records of Jews and refugees living in their departments, and this information was passed to the German authorities. Two months later, as plans were being made for a second convoy from Bordeaux, Papon confirmed to Sabatier's secretary that the German authorities were prepared to exclude children under 16 years of age. Nevertheless, among the 443 detainees aboard the train on 26 August 1942 were numerous under-age victims, including two aged 4 and 9 whose names appear to have been added hastily to the list. Some of the children had been placed in the care of nonJewish families when their parents were arrested. The Bordeaux police had been sent out to arrest them. ${ }^{38}$

The Bousquet-Oberg agreement of July 1942, which paved the way for Vichy collaboration in the mass arrest and deportation of Jews from France, made an exception for French nationals and Jewish spouses of Aryans. Yet on several occasions Papon appears to have casually disregarded this dispensation. Thus in April 1943 Sabatino Schinazi, a French Jew married to a non-Jew, was arrested and detained along with the two eldest of the couple's nine children on the orders of Papon's section for Jewish affairs. Madame Schinazi repeatedly sought to secure their release, and eventually she succeeded in having the two children removed from the Jewish lists. Nevertheless for eighteen months they were detained and on 7 December 1943, despite Madame Schinazi's appeal to Papon, they found themselves on a train bound for Drancy and Auschwitz. It was only by luck that one of two children, Daniel, managed to escape. He and his brother, Samuel, arrested separately for acts of Resistance and later deported to Buchenwald, appeared before the court to recount the family's story. ${ }^{39}$ Marie Reille, the Catholic wife of a French Jew, was also detained in Bordeaux and, despite the willingness of the Germans to allow her to remain behind, she was forced on board a convoy to Drancy on 21 September 1942 by one of Papon's officials. Her journey eventually took her to Poland and through the gates of Auschwitz before the German authorities pulled her from the crowd of women and children awaiting the short march to the gas chambers. With passage provided by the Germans, who apologised for the mix-up, she returned to Bordeaux where she marched to the prefecture to protest to the Director of the Commissariat général aux questions juives at this near-fatal mistake. ${ }^{40}$

As Papon's trial continued the court heard numerous other stories of Papon's conscientious and ostensibly enthusiastic efforts in support of Vichy's 
exclusionist policies. For example, in early July 1942, his order for improved records of Jews and refugees had gone out even though Jean Leguay, the Vichy official responsible for police operations against Jews, was still requesting his colleagues to sit tight and do nothing. ${ }^{41}$ In November 1942, Papon sought and received permission from Darquier de Pellepoix, the CommissionerGeneral for Jewish questions, to cover the shortfall in his budgetary allocation for local anti-Jewish activity by charging expenses to the Union générale des Israélites de France: in other words, charging Jews for their own arrest, detention, sequestration of their property, and the destruction of their community. ${ }^{42}$ As the acte d'accusation noted, when it came to anti-Jewish operations, Papon had displayed a zealous regard for the public purse while 'reacting like a good technocrat, seeking to demonstrate at all times his competence and efficiency. ${ }^{43}$

The Bousquet-Oberg agreement of 1942 called for the deportation of 40,000 Jews, 75 per cent from the German occupied zone and 25 per cent from the 'free' (Vichy) zone, with French Jews making up 40 per cent of the total. Initially only those aged between 16 and 45 years were to be selected, to maintain the fiction that they were destined for resettlement and hard labour in 'the East'. However, German demands for more victims led to the inclusion of the young and old, including the seriously ill, which undercut claims about their eventual fate. Meanwhile, the BBC and other agencies had begun to broadcast the emerging truth about the systematic liquidation of Jews in Poland and elsewhere. ${ }^{44}$ The effect was to diminish public support for Vichy and, with the war turning against the Axis in 1943, the French police became increasingly reluctant to participate in anti-Jewish operations. In 1942, 42,000 Jews had been deported from France; in 1943, the total declined to 16,000. ${ }^{45}$ Papon nevertheless did his best to fulfil his quotas. On his instructions, a convoy of 92 victims was despatched to Drancy on 25 November 1943, another of 136 victims on 30 December, and another of 317 victims on 12 January 1944. The final convoy of 50 victims left Bordeaux on 13 May 1944 , barely more than two weeks before the long-awaited Allied landings in Normandy. ${ }^{46}$ By then, Papon had been instrumental in deporting children as young as 6 months and men and women as old as 87 years, some of them dragged from their hospital beds. ${ }^{47}$

At his trial, Papon's repeated claim that he had not known the terrible fate awaiting the victims rang hollow in face of the evidence presented about contemporary awareness of the Holocaust. As early as the summer of 1942, the court heard, Jews incarcerated in Bordeaux had received word that the Germans had camps where they were systematically exterminating Jews, and by early 1943 reports had circulated that the Germans were using poison gas. ${ }^{48}$ One victim testified that as he was being forced on board the convoy of 26 August 1942, a French police inspector demanded his ration card on the grounds that, 'Là où vous irez, vous n'en aurez plus besoin' ${ }^{49}$ Papon himself, Judge Castagnède pointed out, had betrayed an awareness of their fate by 
employing the term 'deportation' as early as July 1942. Papon lamely denied that the word had carried its current connotation during the war, and suggested that he should have written 'arrest' ${ }^{50}$ He persisted in claiming that no one, not even the Jews in France, had known of the existence of the extermination camps at that time, as evidenced by the shock and disbelief expressed when the camps were liberated in 1944. Prosecuting counsel argued that perhaps he had not known precisely how the Germans would dispose of the Jews, but it had been obvious that, once in German hands, they would be in danger. This alone had been contrary to Papon's duties as a public servant, and made his actions a crime.

\section{Results of the trial}

The trial ended on 1 April 1998, and on 2 April the jury found Papon guilty on 430 of the 768 counts. For this he was sentenced to ten years' imprisonment suspended pending appeal. ${ }^{51}$ Some of the victims or descendants expressed disappointment that the court and jury had stopped short of convicting him of complicity in murder and had sentenced him to less than life imprisonment since, in their opinion, he must have known the fate awaiting those deported from Bordeaux..$^{52}$ But by and large the outcome of the trial met with approval from those directly involved. Judge Castagnède was widely praised for the fairness of the proceedings. Most of the representatives of the Jewish and other deportee organisations affirmed that the verdict provided some release from the terrible sense of disregard they had suffered for so many years. And several of them acknowledged that Pétain's sentence reflected the essential need to distinguish between degrees of complicity. Théo Klein, former president of the Conseil représentatif des institutions juives de France (CRIF) observed that a life sentence might have transformed Papon into an object of sympathy. With the moderate sentence handed down, 'Les juifs ne sont plus en danger, il n'y a pas à avoir peur'. ${ }^{53}$

Most of the fears expressed at the outset of the broader political consequences also turned out to have been unfounded. It had seemed possible that the trial might revive anti-German sentiment in France, but the trial had turned out to be an almost purely franco-français affair. With Papon in the dock and Vichy's reputation under scrutiny, the chief emphasis was on crimes committed by Frenchmen against French men and women. If anything, the trial contributed to a moral levelling of France and Germany, which was more likely to reduce their current differences than increase them. The reputation of the conservative parliamentary parties of France, which also appeared threatened when the trial opened, emerged not merely unaffected but probably enhanced. Several embarrassing references were made during the proceedings to the indifference shown by de Gaulle, Giscard d'Estaing, and other post-war conservative leaders to the fate of Jews in France during the war. ${ }^{54}$ But the trial focused considerably more attention upon the obscure wartime 
activities of Mitterrand, the Socialist leader, whose record as a Vichy official and receipt of Vichy's francisque medal at the hands of Pétain prior to joining the Resistance had aroused a storm of controversy when it became the subject of a recent best-seller. ${ }^{55}$ Until the end of his life Mitterrand betrayed a deep ambivalence about Vichy's record. In contrast, Jacques Chirac, the Gaullist leader and Mitterrand's successor as president of France, had issued a forthright apology for crimes committed by Vichy, in a speech two years before the trial, marking the fifty-third anniversary of the first mass arrest of Jews in Paris in the rafle du Vel d'Hiv. Reference to the speech appeared repeatedly inside and outside the Bordeaux courtroom. At the very least, the trial went some way to reduce the perception of Vichy as a purely right-wing affair. On the other hand, the lengthy presentation of crimes committed against innocent Jews may have contributed to the break-up of the Front National shortly after the trial and its abrupt decline in electoral support.

As for greater public understanding of the past, however, the results of the trial were at best mixed. On the positive side, there is no doubt that the proceedings shed a harsh light on the reactionary and racist character of Vichy, as embodied in its National Revolution. Pétain's claim, made in his own defence after the Liberation, that he had been France's shield while de Gaulle had been its sword, has long been out of favour among academic historians while still widely accepted by the French public. The trial may thus have done something to chip away at the central myth of the Vichy regime, although one cannot be sure. In his final pleading, Alain Jakubowicz, counsel for the Consistoire Israélite de France and the B'nai B'rith, declared it a victory for the Davids over the Goliath of the state. ${ }^{56}$ This, no doubt, is how the surviving victims and their relatives felt, having waited so long for the opportunity to air their grievances. But as Papon's chief counsel was wont to point out, the theatre of the courtroom lent itself to a different interpretation, with one old and physically ailing man in the dock, defending himself against accusations by a small army of lawyers for the interested parties, the state prosecutor, and three judges. For some observers at least, Jakubowicz's biblical analogy must have seemed hopelessly muddled. ${ }^{57}$

The trial almost certainly reinforced a number of other equally ill-founded beliefs, including the popular assumption that support for Vichy and the Resistance had been mutually exclusive. Evidence suggests loyalties and prejudices had not divided on such straightforward lines, and that not a few members of the Resistance may have shared with Vichy a narrow and antisemitic view of the nation. The complexity of the situation is well illustrated by the wartime experience of Georges Kiejman, the former minister and celebrated trial lawyer. Kiejman and his mother, Jewish refugees from Poland, had sheltered in the town of Berri, a small town south of Paris, after the German invasion. Berri being in the German occupied zone, Jews were obliged to wear a yellow star of David, and one day Mrs Kiejman was arrested by a gendarme because her identity card did not identify her as a Jew. Mrs Kiejman 
was haled before a magistrate who, for reasons never made clear, accepted her story that she was not a Jew. The following year, the same gendarme who had arrested Mrs Kiejman was killed while engaged in Resistance activity. ${ }^{58}$ Vichy agent and enforcer of Vichy's anti-semitic laws by day, the gendarme had been a Resistance hero by night. Papon sought to present himself in the court in similar guise, as a Vichy employee who had surreptitiously supported the Resistance throughout the German occupation. But as doubts were cast on his claim to have been an active Resister, the effect was to reinforce the old myth that one could not have been both a Vichyite and a Resister or a Resister and an anti-semite.

Nor was this the only way the trial tended to muddy the historical waters. Because it dwelt almost exclusively upon the wartime persecution of the Jews, it may also have helped to perpetuate the myth of pervasive anti-semitism in pre-war and wartime France. Among the French people, a small but vociferous minority did support Pétain and his anti-semitic, nativist National Revolution to the bitter end. But the great majority displayed almost none of the race hatred that characterised the peasant populations of, for example, Poland, Lithuania, or Hungary. Recent research indicates that from the start of the century and even in the 1930s, amidst almost unprecedented crises and increasing anti-semitism elsewhere, anti-semitism in France continued to decline. ${ }^{59}$ The French population acquiesced in Vichy's policies because they looked to Pétain for protection, but they soon became disaffected when Hitler disregarded Pétain's efforts to secure a peace settlement and the return of prisoners of war. Prefects reported widespread public dismay and outrage once the mass arrests of Jews began. ${ }^{60}$ Suffice it to note the observation of Serge Klarsfeld, Europe's leading Nazi hunter, which was repeated during the trial in response to Papon's claim that Vichy saved proportionately more Jews than other governments in occupied Europe. The one-quarter of France's Jews who perished during the war passed through Vichy's hands. The three-quarters of France's Jews who survived did so because of the Resistance and the many unrecorded acts of humanity by individual French men and women. ${ }^{61}$ Nevertheless, with the trial devoted exclusively to French collaboration in the Holocaust, the almost inevitable impression created was of a wartime France fixated by anti-semitism.

As for Papon's motives, it may be that the trial was equally misleading, notwithstanding the mountain of evidence presented about his wartime activities. At first glance, it must seem obvious that he was motivated by antisemitism, since so many Jews suffered and died as an indirect result of his actions. Certainly the policies he so vigorously implemented were monstrous and their consequences horrifying. Yet, as the court heard, the charge of antisemitism did not square with his prewar record of liberal, anti-racist activity. Nor did the conflicting evidence end with the outbreak of war. Among his contemporaries within the Ministry of the Interior, Papon's closest friend was Maurice Lévy. Although a Jew, Lévy had been exceptionally allowed to 
remain in post after the introduction of the statut des juifs because of his distinguished war record in 1939-40, which included decorations for bravery. In 1942 Lévy sought to accompany Papon when he went to Bordeaux, and was dissuaded by Sabatier who pointed out that the Germans would not accept Jews in the Prefecture there. ${ }^{62}$

Marc-Olivier Baruch, the author of a widely praised history of the higher civil service under Vichy and one of the historians who appeared as an expert witness at Papon's trial, referred to the existence of latent anti-semitism within the higher civil service. But, as he explained to the court, it had not been anti-semitism that had driven them to participate in the Holocaust, but rather their loyalty to the state and the logic of Vichy's National Revolution. ${ }^{63}$ According to his published account, no more than a handful of senior functionaries had been enthusiastic about the National Revolution itself. ${ }^{64}$ One imagines that Sabatier, Papon's superior, had not been among them since, the court heard, his wife was a Jew. ${ }^{65}$ There are abundant grounds for doubting that Papon had been any more enthusiastic. Arno Klarsfeld forthrightly acknowledged towards the end of the trial that, in his view, Papon had not acted out of personal animus against the Jews and hence was not to be regarded as anti-semitic. ${ }^{66}$ Jakubowicz and Gérard Boulanger, two other leading counsel for the interested parties, echoed Klarsfeld's view. So, too, did Serge July, editor of the national liberal daily, Libération, whose leading article at the conclusion of the trial affirmed:

Maurice Papon ne fut ni un partisan de la révolution nationale, ni un militant de la collaboration avec l'Allemagne, il n'était même pas anti-sémite. A cet égard, it était exemplaire d'une caste qui a compté aussi, à cette époque, ses héros emblématiques.

Maurice Papon était simplement sécrétaire général de la préfecture. Il vient d'être condamné non pour un militantisme tragique en faveur d'une idéologie monstreuse, mais pour son activité de haut fonctionnaire autoritaire, efficace et indifférent à la portée de ses actes ...

L'idéologie administrative, lorsqu'elle est laissée à elle-même, peut engendrer des criminels de bureau. Il n'en sont pas moins criminels. C'est ce que vient de rappeler opportunément le verdict de Bordeaux. ${ }^{67}$

The view that Papon's crimes represented the behaviour of a man driven by personal ambition and working within a bureaucracy jealous of its authority, strongly hierarchical, and remote from the citizens whose lives were damaged or destroyed by its actions, found favour among a remarkable number of observers as the trial ended. Caroline Daigueperse, respresenting the Consistoire central, the Union des communautés juives de France, B'nai B'rith, and the Jews of Bordeaux, described Papon as having acted 'comme un fonctionnaire, un bureaucrate qui se retranche derrière un organigramme administratif, la hiérarchie, l'obéissance aux ordres' ${ }^{68}$ Bertrand Favreau, representing the Ligue des Droits de l'homme, spoke of Papon's 'crime de papier . . . anonyme, segmenté, 
froid ... le fruit d'une chaîne de services' ${ }^{69}$ Michel Zaoui, representing the Association amicales des déportés d'Auschwitz et des camps de Haute-Silésie and other deportees' groups, spoke of 'ce crime administratif, ce crime de bureau, se distingue par l'éloignement du bureaucrate de sa victime', and he quoted Franz Kafka that 'les chaînes de l'homme torturé sont faites en papiers de ministères'. ${ }^{70}$ Boulanger described Papon as a bureaucratic criminal, 'un technicien de commandement de la morgue'. ${ }^{71}$ Le Monde's chief diarist, the distinguished author Bertrand Poirot-Delpech, entitled his account of the trial Papon: un crime de bureau. In his view, the trial revealed Papon to have been a selfish authoritarian type, deferential to his superiors, coldly indifferent to his inferiors, a typical product of a higher civil service that had become indifferent to the nation it was supposed to serve and that served only itself. For him and like-minded critics, the lesson of the trial was that the upper civil service must be sensitised to its actions and encouraged to dissent on moral grounds whenever policies breached principles of republican justice.

It is no doubt true that the higher civil service in pre-war and wartime France was an exclusive and self-consciously elitist institution, that Papon, at least by the time of the trial in Bordeaux, appeared arrogant and indifferent to the fate of the victims, and that his wartime office occupied an intermediate place in a long and extremely complicated chain of command. Yet, even granting these points, the common view of his behaviour that emerged at the end of the trial seems unconvincing. One reason for his dissembling and cold, almost repellent, manner in the Bordeaux courtroom may be attributable to his advancing years and resentment at being made the scapegoat for the whole Vichy state. It was almost certainly due in part to the adversarial character of the trial, which led him to adopt the strategy of denying responsibility for everything and apologising for nothing. ${ }^{72}$ It was further coloured by the image presented by Varaut, his chief legal counsel, whose confidence, apparent disdain for the victims, and royalist politics made him seem a throwback to the Pétainiste circles of the $1940 \mathrm{~s}^{73}$ Added to this was the fact that, as Papon aged, he had moved increasingly in conservative circles, becoming remote from his youthful self. A tall, handsomely turned out octogenarian whose memory and repartee were often remarkably acute, it was all too easy to forget that the court was trying a young man who had arrived in Bordeaux fifty years earlier to assume responsibilities that in ordinary circumstances were well beyond those imposed on a 32-year-old.

As for the peculiarities of the French higher civil service as a whole, criticism of its remoteness and indifference to the consequences of its actions must be put into context. Not just France, but every country that has succeeded in establishing responsible government and the rule of law, has had to create a disciplined civil service, willing to resist the temptations of financial gain or political favouritism, and to subordinate itself to the will of its political masters. The French civil service was a Napoleonic creation, which bore a close resemblance to the military in structure and ethos. It took time to become 
professionalised and depoliticised, but the process was largely completed by the last quarter of the nineteenth century if not before. Like the French army, which was popularly known as la grande muette (the silent service), the higher civil service existed to do the bidding of the legally constituted government, whether of empire, monarchy, or republic, and whatever its political stripe.

This was the service that Papon joined in 1935: a time when France faced acute threats of internal social and political strife as well as possible attacks from Italy and Germany. Civil service tradition required him to set aside partisan politics, which he appears to have done more or less. But it did not require the suppression of the Jacobin patriotism which formed the core of his political beliefs. By then the French higher civil service had come to be regarded not merely as a source of secure employment but as a calling, 'something noble', in the words of two of the leading post-war officials who entered the service at virtually the same time as Papon. ${ }^{74}$ Devotion to duty became all the more compelling when the French army was defeated in 1940 and the civil service found itself standing alone between the nation and the German occupiers, who proceeded to partition the country, detaching several parts from French control, handing over another to Italy, and absorbing one completely into the Reich. The reaction of officials such as Papon was to serve with greater discipline than ever. As several observers were to point out scornfully, the same higher civil service that had served the public good under the previous seventy years of republican government became a highly effective instrument of injustice when the Vichy state was created. It was, therefore, all too easy to portray Papon's career as a case of opportunism or moral relativism, in which he had moved effortlessly from serving the liberal Third Republic to authoritarian Vichy, then the liberal Fourth Republic, and finally de Gaulle's and Giscard d'Estaing's conservative Fifth Republic. ${ }^{75}$ But to Papon himself, no doubt, this was precisely the point: the duty of higher civil servants was to ensure the continuity of the state, whoever was politically in charge. In the same way, prosecuting counsel argued that Papon's ruthless efficiency and personal ambition were evidence of his flawed personality because of the tragic consequences of his actions. Yet it is only fair to note that capable, ambitious individuals are everywhere sought after to ensure the efficient running of state bureaucracies.

In the summer of 1939 Papon had requested permission to join the army, which was not the action of a coward. While he was overseas, the Third Republic gave way to the Vichy Etat français, an act whose constitutionality has been widely questioned since 1945, but which went largely unquestioned in wartime France. Practically no one in public life, not even de Gaulle, was prepared to speak up for the Third Republic, which appeared to have failed calamitously, and Vichy's legitimacy seemed established by the overwhelming vote of deputies and senators in favour of according Pétain emergency powers. Papon's decision to accompany Sabatier to Bordeaux in the spring of 1942 
was consistent with his earlier behaviour. Bordeaux, southern anchor of Germany's Atlantic wall and a major submarine base, lay firmly inside the occupied zone. Vichy's decision to send such a senior civil servant as Sabatier reflected its determination to maintain French authority in the city and stop it slipping completely into Germany's New Order. Papon, it seems reasonable to assume, shared this preoccupation: a pressing and ostensibly vital one at a moment when Germany appeared to have won decisively in the West and was still on the offensive in the East. It is almost certainly for this reason that Sabatier, Papon, and Lévy were prepared to leave the relative comfort of Vichy to live under the constant surveillance of the Germans in Bordeaux, and for Sabatier and Papon to follow orders from Vichy despite their brutal consequences.

Viewed in this light, the motives that drove Papon to assume responsibility for the 'Jewish question' in Bordeaux were, to all intents and purposes, no different from those that prompted his compatriots to join the Free French in London or the Resistance within France. In each case the crucial impetus was patriotism. The difference between them lay not with personal ambition or moral blindness, but largely the circumstances in which they found themselves and the practical consequences of their actions. This in no way diminishes the awfulness of the crimes for which Papon was charged and convicted. It may be agreed that there is something particularly monstrous about participating in the arrest of innocent and vulnerable men, women, and children, and handing them over to an enemy manifestly bent upon abusing them, even if one did not know what would actually happen to them. Papon, having chosen to carry out these acts, bore some responsibility for the consequences and hence was guilty of crimes against humanity. ${ }^{76}$ But it is perhaps too easy to forget the moral compromises required of all those who were prepared to defend France, including the Free French forces who carried out the systematic bombing of large civilian concentrations in German towns and cities, and the Resisters whose acts of sabotage enabled the Germans to present them as terrorists and provoked the execution of innocent hostages. In every case, love of country at a time of unprecedented crisis led people to behave as if the end justified the means. It is now widely accepted that Pétain and the Vichy regime were too little concerned with national liberation and too much preoccupied with their reactionary National Revolution to warrant comparison with the other two French wartime forces. This undercuts the moral legitimacy of a Vichy agent such as Papon. Yet his patriotism, however misdirected, seems to have been real enough. ${ }^{77}$ For all its efforts to expose the truth about Papon's responsibility for the fate of the 1,560 deportees from Bordeaux, the assize court was ultimately not very helpful in establishing the motives for his acts. This was perhaps the greatest shortcoming of the trial. But in fairness to those involved, historians are seldom much better than lawyers in unravelling the conundrum of human volition. 


\section{Notes}

1 The composition, occupation, and age of the jurors are given in J.-A. Fralon, 'Pendant l'attente: "La nuit est dure, mais c'est le bout du chemin"', Le Monde (3 April 1998), p. 6. See also Le Procès de Maurice Papon, tome 1, 8 octobre 19978 janvier 1998 (Paris: Albin Michel, 1998), p. 33. This is the most complete, albeit still far from comprehensive, transcript of the trial. Where appropriate, the author has drawn from other sources, notably the transcript compiled by Usha and JeanMarie Matisson for the victims and interested parties and made available through the internet at www.matisson-consultants.com/affaire-papon (hereafter Matisson MS).

2 The Ministry of Justice estimated the cost at 15 million francs. P. Nivelle, 'Insolvable, Papon doit 4,6 millions de francs', Libération (4 April 1998).

3 'Parmi les records battus par le procès, il y aura eu celui de la couverture médiatique', B. Poirot-Delpech, Papon: un crime de bureau (Paris: Editions Stock, 1998), p. 68.

4 N. Weill, 'Le souvenir amer d'une répression parfois défaillante', Le Monde Supplément (1 October 1997), p. vii.

5 Aside from Germany, obviously a special case, France thus became the only country to put its own nationals on trial for crimes against humanity committed during the Second World War. R. O. Paxton, 'The Trial of Maurice Papon', The New York Review (16 December 1999), p. 32.

6 The charges and summaries of the court record of those facing trial since the 1970 s are conveniently compiled in S. Chalandon and P. Nivelle (eds), Crimes contre humanité: Barbie, Touvier, Bousquet, Papon (Paris: Librairie Plon, 1997).

7 Statement by the avocat général, Marc Robert, 9 October 1997, Procès, t. 1, p. 45.

8 ('If you weren't twenty in 1940, you have nothing to say about Vichy.') Mitterrand had also described the law specifying crimes against humanity of 1964, which was to apply retroactively to the wartime period as 'a political settling of scores'. S. Denis, 'De Gaulle disait "Les fonctionnaires sont faits pour fonctionner." Toute la carrière de Papon le preuve. Sans états d'âme', www.Parismatch.fr, n.d.

9 Indications that Mitterrand may have discouraged the trials are summarised in Poirot-Delpech, Papon, pp. 453-4. See also P. Péan, Une jeunesse française: François Mitterrand 1934-1947 (Paris: Fayard, 1994), pp. 313-20, 516-21; A. Klarsfeld, La Cour, les nains et le bouffon (Paris: Robert Laffont, 1998), pp. 80-1; 'La fin d'un marathon juridique', Libération (24 January 1997). However, Henri Nallet, garde des Sceaux (lord chancellor), and Georges Kiejman, the deputy minister of justice, categorically denied any interference by Mitterrand in Bousquet's trial and by implication other trials of Vichy officials. See J. Lacouture, Mitterrand: une histoire d'un français, t. 2: Les vertiges du sommet (Paris: Editions du Seuil, 1998), pp. 52933.

10 Procès, t. 1, pp. 675-6 (statements by Jean-Marc Varaut and Jean Serge Lorach, 11 December 1997).

11 Ibid., pp. 77-8 (letter read to the court by the presiding judge, Jean-Louis Castagnède, and statement by Varaut, 13 October 1997). Varaut did not fail to exploit Rousso's absence, see ibid., p. 317 (31 October 1997), and t. 2, pp. 872, 875 (24 March 1998). On the dangers of merging the functions of historical investigation and courtroom, see J.-N. Jeanneney, Le Passé dans le prétoire: l'histoire, le juge, et le journaliste (Paris: Editions du Seuil, 1998); H. Rousso, La Hantise 
du passé (Paris: Textuel, 1998); J. D. Bredin, 'A quel moment faut-il choisir de désobéir?'; and P. Nora, 'l'impossible imprescriptibilité', in Poirot-Delpech, Papon, pp. $455-8,463-4$.

12 See, for example, the testimony of Maurice Druon, secrétaire perpétuel of the Académie Française, Procès, t. 1, p. 297 (22 October 1997).

13 J.-L. Einaudi, La bataille de Paris: 17 octobre 1961 (Paris: Editions du Seuil, 1991). At Papon's instigation, Einaudi was charged with criminal libel, but was acquitted after a weeklong trial in February 1998.

14 C. Chambraud, 'La droite est partagé sur l'analyse du régime de Vichy', Le Monde (23 October 1997). A useful survey of the hopes and fears aroused by the trial is set out by the documentary filmmaker M. Halter, 'Le désastre du procès Papon', Libération (29 December 1997).

15 See below, pp. 170-1.

16 G. Boulanger, Maurice Papon, un technocrat français dans la collaboration (Paris: Editions du Seuil, 1994), p. 28 and passim; P. Miquel, Les quatre-vingts (Paris: Fayard, 1995), p. 246.

17 E. Weber, Action Française: Royalism and Reaction in Twentieth-Century France (Stanford: Stanford University Press, 1962), pp. 157-9.

18 Procès, t. 1, p. 372, (testimony of Papon, 3 November 1997).

19 Ibid., t. 2, p. 861, (statement by Francis Vuillemin, 23 March 1998).

20 Ibid., t. 1, pp. 183-8, 371-2 and passim (testimony of Papon, 15 October and 3 November 1997); also Boulanger, Maurice Papon, pp. 26-30; B. Violet, Le Dossier Papon (Paris: Flammarion, 1997), passim; P. Nivelle, 'Jeune homme de cabinets', www.libération.fr/papon/Procès/histoire1.htm.

21 R. O. Paxton, Vichy France: Old Guard and New Order, 1940-1944 (London: Barrie \& Jenkins, 1972), p. 174; D. Peschanski, 'Exclusion, persécution, répression', in J.-P. Azéma and F. Bédarida (eds), Vichy et les français (Paris: Fayard, 1992), pp. 209-34.

22 Procès, t. 1, pp. 368-71 (testimony of Papon, 3 November 1997); Matisson MS, 'Attributions de Papon au Ministère de l'Intérieur entre 1940 et 1942: éléments de l'interrogatoire de l'accusé par l'avocat général Robert - audience du 3.11.1997'.

23 N. Weill, 'Bordeaux ou les délices de l'accommodation', Le Monde Supplément (1 October 1997), p. iii.

24 Procès, t. 1, p. 514 (cross-examination by Castagnède, 14 November 1997).

25 The claim was corroborated in the testimony of Marguerite Bonnecaze, ibid., t. 2, pp. 8, 12 (9 January 1998).

26 Ibid., t. 1, p. 712 (testimony of Papon, 12 December 1997); see also ibid., p. 721 (15 December 1997); but see J. Amalric, 'Confondant', Libération (3 December 1997).

27 Procès, t. 2, p. 518 and passim (testimony of Papon, 14 November 1997). Papon's defence is summed up by Varaut at ibid., pp. 869-945 (24, 30, 32 March and 1 April 1998).

28 Ibid., t. 1, pp. 438, 613 (testimony of Papon, 6 November and 8 December 1997).

29 Ibid., pp. 438-9 (6 November 1997).

30 Ibid., p. 610 (8 December 1997).

31 Ibid., p. 405 (4 November 1997), t. 2, pp. 432, 445 (11 February 1998).

32 Ibid., t. 1, p. 393 (4 November 1997).

33 Ibid., t. 2, pp. 524-5 (cross-examination by Castagnède, 18 February 1998). 
34 ' $\mathrm{M}$ e Blet passe au crible la défense de ce "résistant du débarquement"', Le Monde (13 March 1998).

35 Bernard Bergerot, director of personnel at the Ministry of the Interior from 1951 to 1958, concurred with Papon's interpretation, Procès, t. 1, p. 452 (7 November 1997); but see, for example, the testimony of Marc-Olivier Baruch, ibid., p. 422 (5 November 1997). According to Alain Lévy, counsel for the Fédération nationale des déportés et internés résistants et patriotes (FENDIRP), Papon and his defence wilfully confused administrative law and penal law in their attempt to shift responsibility to superiors, Matisson MS, Maître Lévy, 'Klaus Barbie et Papon ont tous deux pris la vie des enfants', p. 13.

36 See, for example, the exchange between the procureur général, Henri Desclaux, and Papon, ibid., t. 2, pp. 98-100 (15 January 1998).

37 Ibid., t. 1, pp. 109, 162, 622-5, 630; Boulanger, Maurice Papon, pp. 82-4.

38 Procès, t. 1, p. 120 (acte d'accusation); ibid., p. 882 (cross-examination by Castagnède, 23 December 1997).

39 Ibid., t. 2, pp. 193-7 (cross-examination by Robert, 26 January 1998), pp. 204-9 (testimony of Samuel Schinazi, 27 January 1998), pp. 209-19 (testimony of Moïse Schinazi, 27 January 1998).

40 Ibid., t. 2, pp. 38-44 (testimony of Yvette Silva, 12 January 1998).

41 Ibid., t. 1, pp. 691-4 (cross-examination by Castagnède, 11 December 1997), pp. 743-50 (cross-examination by Robert, 16 December 1997).

42 Ibid., t. 2, pp. 175-6 (cross-examination by Castagnède, 23 January 1998).

43 Ibid., t. 1, p. 144 (acte d'accusation).

44 Ibid., pp. 158-61 (acte d'accusation), p. 334 (statement by Bertrand Favreau, 31 October 1997).

45 Ibid., pp. 310 (testimony by R. O. Paxton, 31 October 1997).

46 Ibid., p. 108 (acte d'accusation).

47 Ibid., t. 2, pp. 31, 439-41 and passim (evidence presented by Robert).

48 Ibid., p. 205 (testimony by Simon Schinazi, 27 January 1998).

49 ('Where you're going, you won't need this any more'.) Chalendon and Nivelle (eds), Crimes contre humanité, p. 418.

50 Procès, t. 1, p. 696 (testimony of Papon, 11 December 1997). See also Chalendon and Nivelle (eds), Crimes contre humanité, pp. 398, 408.

51 In addition, the court demanded 4.6 million francs from Papon for costs and compensation to the victims, P. Nivelle, 'Insolvable, Papon doit 4,6 millions de francs', Libération (4 April 1998).

52 The disappointed included Alain Lévy, counsel for the Fédération nationale des déportés et internés résistants et patriotes, Bertrand Favreau, counsel for the Ligue des Droits de l'homme, Gérard Boulanger, counsel for several of the surviving victims, and Juliette Benzazon, the widow of one of the victims. Matisson MS, 'Les réactions au verdict', 15 April 1998.

53 ('Jews are no longer in danger, there is no more cause for fear'.) D. Licht, 'Quasiunanimité autour du verdict: politiques et associations saluent la valeur pédagogique du procès', Libération (4 April 1998). Among others who welcomed the verdict were Dominique Delthil, counsel for SOS-Racisme, Joë Nordmann, counsel for FENDIRP, Caroline Daigueperse, counsel for the Association cultuelle israélite de la Gironde, the Consistoire central, the Union des communautés juives de France, and B'nai B'rith, and Arno Klarsfeld, counsel for the Association des fils et filles des 
déportés juifs de France, Maurice-David Matisson, a surviving victim, Samuel Pisar, a leading member of the French Jewish community, Grand Rabbis Maman and Sitruck, and Henri Hajdenberg, President of the Conseil représentatif des institutions juives de France (CRIF), Matisson MS, 'Les réactions au verdict', 15 April 1998. See also J.-A. Fralon, 'Pendant l'attente: la nuit est dure, mais c'est le bout du chemin', Le Monde (3 April 1998), p. 6.

54 See, for example, Procès, t. 1, pp. 313, 412, 414, t. 2, p. 729.

55 In 1992 Mitterrand himself added to the controversy by placing a flower on Pétain's tomb. See ibid., t. 1, p. 333 (cross-examination by Lévy, 31 October 1997), and t. 2, p. 698 (statement of A. Klarsfeld, 10 March 1998).

56 Matisson MS, 'Pour l'éternité', 12 March 1998.

57 On preliminary public reactions to the trial, see N. Weill, 'Une contribution ambiguë à l'historiographie de Vichy', Le Monde (3 April 1998), p. 9; also 'Réactions', ibid., p. 9.

58 R. Bernstein, 'French collaborators: the new debate', New York Review (25 June 1992), p. 41.

59 R. Rémond, 'L’opinion française des années 1930 aux années 1940. Poids de l'événement, permanence des mentalités', in J.-P. Azéma and F. Bédarida (eds), Vichy et les Français (Paris: Fayard, 1992), pp. 490-1.

60 Procès, t. 1, p. 351 (testimony of J.-P. Azéma, 3 November 1997), t. 1, p. 409 (testimony of René Rémond, 4 November 1997).

61 Ibid., t. 1, p. 357 (testimony of Azéma, 3 November 1997), p. 601 (statement by A. Klarsfeld, 8 December 1997).

62 Ibid., p. 394 (testimony of Papon, 4 November 1997).

63 Ibid., p. 420 (testimony of Baruch, 5 November 1997).

64 Baruch, Servir l'état français, pp. 168-9, 201 and passim.

65 Procès, t. 1, p. 290 (testimony of Mme Chapel, 22 October 1997).

66 Ibid., t. 2, pp. 690, 703 (statement by A. Klarsfeld, 10 March 1998).

67 ('Maurice Papon was neither a partisan of the National revolution nor a militant of collaboration with Germany, he was not even anti-semitic. In this regard, he was exemplary of a caste which had, at this time, its emblematic heroes. Maurice Papon was simply secretary-general of the prefecture. He has just been condemned, not for a tragic militancy in favour of a monstrous ideology, but for his activity as a senior civil servant in which he was authoritarian, efficient and indifferent to the consequences of his actions ... The administrative ideology, given free rein, can engender bureaucratic criminals. They are not less criminals. This is what the verdict in Bordeaux has opportunely signalled.') S. July, 'La fin des intouchables', Libération (4 April 1998).

68 ('as a coward, a functionary, a bureaucrat, who hid behind the organisation chart of the administration, the hierarchy, obeying orders'.) Matisson MS, 'Maître Daigueperse: "Vous proclamerez haut et fort l'alliance de la morale et de la justice”, 10 March 1998. Klarsfeld presented a similar explanation in his account of the trial, La Cour, p. 26.

69 ("crime by official documentation . . . anonymous, compartmentalised, callous ... the result of a chain of command'.) Matisson MS, 'Maître Bertrand Favreau: "Mille cinq cent soixante fois une vie"', 13 March 1998.

70 ('this administrative crime, this bureaucratic crime, whose feature is the distance of the bureaucrat from his victim'), ('the chains of tortured humanity are made of 
ministerial paper work'). Ibid., 'Michel Zaoui "la spécificité du crime administratif”, 16 March 1998.

71 ('a technician from the morgue'.) Ibid., G. Boulanger, 'Le premier contre l'humanité est constitué dès que le premier homme a été tué parce qu'il est né' (9 March 1998).

72 Procès, t. 1, p. 69 (statement by Zaoui, 13 October 1997); ibid., t. 2, pp. 854-5 (statement by Vuillemin, 23 March 1998).

73 Varaut had, in fact, written a sympathetic account of Pétain, Le procès Pétain: 1945-1995, and this was the object of a sustained attack by one of the prosecuting counsel. Matisson MS, Maître R. Blet, 'Ce numéro 41796 restera toujours sur le bras de monsieur Balbin, mais au moins il pourra lever son bras avec fierté,' 11 March 1998.

74 F. Bloch-Lainé and C. Gruson, Hauts fonctionnaires sous l'occupation (Paris: Odile Jacob, 1996), pp. 29, 130.

75 One counsel for the interested parties called him a chameleon, Klarsfeld, La Cour, p. 125, another 'une espèce d'ectoplasme qui peut vivre dans n'importe quel milieu' ('a sort of ectoplasm capable of living in any sort of condition'), Matisson MS, Maître Charrière-Bournazel, 'De ces âmes errantes vous êtes, comme moi, les petits frères inconsolés', 16 March 1998. See also P. Birnbaum, 'Les fonctionnaires contre la République', l'Arche: le mensuel du judaïsme français, www.col.fr/arche/ arguments.htm

76 On Papon's guilt compared to that of Adolf Eichmann, Klaus Barbie, Paul Touvier, and René Bousquet, see the table of comparison in Klarsfeld, La Cour, pp. 230-1.

77 Baruch, almost alone among witnesses, affirmed this point, Procès t. 1, pp. 422-3 (5 November 1997). 